Thabiea: Journal of Natural Science Teaching
Program Studi Tadris Ilmu Pengetahuan Alam
Institut Agama Islam Negeri Kudus
http://journal.stainkudus.ac.id/index.php/Thabiea
$p$-issn: 25808474

\title{
Pengembangan Panduan Pembuatan Media Taktil yang Diaplikasikan Dalam Pembelajaran IPA
}

\section{Nur Kholifah ${ }^{1, a}$}

${ }^{1}$ STITNU Al Hikmah Mojokerto, Jalan Hayam Wuruk No. 31, Watesumpak, Trowulan, Mojokerto, Jawa Timur 61362

a ifa_ebi@yahoo.com

\begin{tabular}{ll}
\hline Kata Kunci & ABSTRAK \\
\hline Panduan Pembuatan Media & Penelitian ini bertujuan untuk mengembangkan panduan pembuatan media \\
Taktil & taktil yang diaplikasikan dalam pembelajaran IPA. Hal ini dilakukan karena \\
Pembelajaran IPA & pembelajaran IPA di SD dewasa ini masih memerlukan usaha untuk \\
Kreativitas & memenuhi harapan kurikulum yang berlaku. Kreativitas dan hasil belajar \\
Hasil Belajar Kognitif & kognitif anak terhadap pembelajaran IPA sangat rendah. Kesulitan yang \\
& mereka peroleh memerlukan media yang kongkrit dalam pembelajaran. \\
& Penelitian ini bertujuan untuk menerapkan panduan pembuatan media taktil \\
& untuk membuat media yang diaplikasikan dalam pembelajaran IPA kemudian \\
& dilihat keefektifannya terhadap kreativitas dan hasil belajar kognitif peserta \\
& didik. Subjek penelitian adalah peserta didik kelas 4 SD Negeri Entalsewu \\
& tahun pelajaran 2016/2017 sebanyak 25 orang. Hasil penelitian diperoleh \\
& bahwa panduan yang dikembangkan secara umum berkategori baik, dengan \\
& nilai N-Gain tes hasil kreativitas, yang diperoleh pada posttest dan pretest \\
& dengan rentang skor 0,9, yang artinya rentang skor tersebut tinggi. Ketuntasan \\
& tes hasil belajar kognitif secara klasikal posttest tuntas dengan prosentase \\
& $100 \%$.
\end{tabular}

Key word
Creating tactile media
guidance book
Learning Science
Creativity
Cognitive Learning Outcomes

\begin{abstract}
Development of "Greater" Learning Model on Chemistry Learning as an Effort to Embed Students' Science Literacy. This research had purpose to develop of the creating tactile media applied to science learning. It can be done because of learning science in elementary school today still require effort to meet the expectations of the applicable curriculum. Creativity and cognitive learning outcomes of children towards science learning was very low. Difficulties they earn require concrete media in learning. This study aimed to apply the guidance manufacture tactile media to create media that was applied in science learning is then seen its effectiveness against creativity and cognitive learning outcomes of students. The subjects were students 4 th grades elementary school Entalsewu 2016/2017 as many as 25 students. The result showed that the general guidelines developed was in good category, with a value of $\mathrm{N}$-Gain creativity test results, obtained in the posttest and pretest with a range of scores 0.9 , which means the higher the score range. The overall of testing the cognitive learning classically posttest were complete with a percentage of $100 \%$.
\end{abstract}

Copyright $\odot 2018$ Institut Agama Islam Negeri Kudus. All Right Reserved

\section{Pendahuluan}

Pembelajaran monoton menyebabkan peserta didik menjadi tidak tertarik atau kurang menghayati pengalaman belajarnya (Beetlestone, 2012). Berdasarkan kenyataan tersebut perlu dikembangkan suatu media pembelajaran yang menarik mengembangkan kreativitas peserta didik.
Media taktil atau tiruan dalam proses pembelajaran akan mempermudah peserta didik untuk mempelajari kembali materi yang disajikan melalui media yang telah diciptakan dengan berbagai inovasi dan kreativitas yang dimunculkan. Agar perilaku kreatif dapat terwujud, baik ciri-ciri kognitif maupun afektif (sikap dan nilai) dari kreativitas perlu dikembangkan secara terpadu dalam proses 
belajar. Perlu adanya suatu pengembangan panduan pembuatan media taktil yang diaplikasikan dalam pembelajaran IPA serta keefektivannya terhadap kreativitas dan hasil belajar kognitif peserta didik.

Santrock (1998) menjelaskan secara umum media dapat memberikan umpan balik yang segera kepada peserta didik sehingga peserta didik merasa pembelajaran lebih interaktif. Dari pembelajaran yang interaktif akan meningkatkan pemahaman peserta didik dalam kegiatan belajar mengajar. Torrance (dalam Siswono, 2005) mengatakan agar potensi kreatif individu dapat diwujudkan, diperlukan kekuatan-kekuatan dari luar yang didasari oleh potensi dalam diri individu dalam mewujudkan kreativitas. Hal ini diperkuat oleh pendapat Clausnitzer (1994) yang menyatakan bahwa media tiga dimensi dapat memperkuat pemahaman peserta didik

Berdasarkan uraian latar belakang di atas, maka perlu dikembangan panduan pembuatan media taktil terlebih dahulu yang kemudian diterapkan di kelas untuk melatihkan kreativitas dan hasil belajar kognitif. Tujuan dari penelitian ini untuk mendeskripsikan validitas, kepraktisan, dan keefektifan panduan pembuatan media taktil yang dikembangkan dengan model PBL (Project Based Learning). Produk media yang dihasilkan kemudian diaplikasikan di dalam pembelajaran. Selanjutnya kreativitas dan hasil belajar kognitif peserta didik di ukur.

\section{Metode}

Penelitian ini merupakan penelitian pengembangan (research development). Subjek penelitian ini adalah peserta didik kelas IV semester 2 pokok bahasan energi dan kegunaannya. Penelitian dilaksanakan dalam dua tahap. Tahap pertama adalah tahap pengembangan panduan pembuatan media taktil dan tahap kedua adalah tahap penerapan panduan pembuatan media taktil dengan model berbasis proyek. Pengembangan panduan pembuatan media taktil dalam penelitian ini, mengikuti model pengembangan Four-D Model yang dikemukakan oleh Thiagarajaan (dalam Ibrahim 2008). Pada penelitian ini hanya tiga tahap saja yang dilaksanakan yaitu: mendefinisikan, merancang, dan mengembangkan.

Teknik pengumpulan data yang dilakukan menggunakan teknik. Telaah/validasi meliputi, panduan pembuatan media, dan perangkat pembelajaran, yang dilakukan oleh para pakar yang memiliki otoritas keilmuan. Pengamatan adalah kegiatan pengamatan perhatian terhadap suatu objek dengan menggunakan seluruh indera. Observasi/pengamatan bertujuan untuk mengumpulkan data tentang keterlaksanaan panduan sesuai dengan yang tercantum dalam RPP selama pembelajaran berlangsung. Pemberian tes dilakukan dua kali yaitu sebelum pembelajaran (pretest) dan setelah pembelajaran (posttest). Penilaian digunakan Tes hasil belajar ini digunakan untuk menentukan ketuntasan pencapaian TPK. Pemberian angket diberikan kepada peserta didik setelah mereka menyelesaikan kegiatan pembelajaran. Tehnik pemberian angket berupa tes, angket tertulis (angket kemenarikan dan keterbacaan peserta didik)

Data yang yang dikumpulkan dalam penelitian ini dianalisis menggunakan statistik deskriptif kualitatif. Hasil analisis kuantitatif kemudian dideskripsikan secara kualitatif. Analisis data validasi isi terhadap panduan divalidasi oleh validator dengan skala penilaian dalam setiap komponen adalah 1-4. Analisis data kemenarikan dengan teknik analisis data secara deskriptif kuantitatif. Analisis tingkat keterbacaan panduan pembuatan media diukur dengan teknik persentase yaitu persentase dari jumlah kalimat yang dapat dilengkapi dengan jumlah keseluruhan kalimat yang harus dilengkapi dikalikan 100\%

Analisis pengamatan keterlaksanaan penggunaan panduan dilakukan oleh dua orang pengamat yang sudah dilatih dengan memberikan tanda cek (v) pada kolom keterlaksanaan (ya atau tidak) dan pada kolom penilaian (5:sangat baik, 4: baik, 3:cukup baik, 2:kurang baik, 1:tidak baik). Analisis data 
kendala selama pembelajaran diperoleh melalui catatan-catatan peneliti dan pengamat selama berlangsungnya proses pembelajaran.

Analisis data kreativitas peserta didik diperoleh dengan menggunakan tes berpikir kreatif berupa soal yang dikerjakan pada awal dan akhir pertemuan. Analisis data tes hasil belajar peserta didik adalah deskriptif kuantitatif.

\section{Hasil dan pembahasan}

\section{Kelayakan}

\section{a. Validasi Panduan dan Perangkat Pembelajaran}

Penelitian ini diawali dengan pengembangan panduan, kemudian mengimplementasikan panduan ke dalam proses belajar mengajar. Proses pengembangan yang dilakukan oleh peneliti berhasil mengembangkan panduan yang digunakan untuk pembutan media taktil berupa media tiruan (kincir angin, mobil udara, dan termometer). hasil penilaian dari validator untuk komponen kelayakan isi panduan adalah 3.5, kelayakan penyajian 3,2, dan komponen bahasa 3,3 , sehingga total rerata untuk 3 komponen tersebut adalah 3,3 yang dikategorikan valid (Ratumanan, 2006).

Hasil validasi dikategorikan valid karena dalam pembuatan panduan tersebut telah ditelaah sesuai dengan karakteristik peserta didik, sehingga dapat dimengerti oleh peserta didik. Penulisannya sistematis sehingga peserta didik tidak bingung dengan panduan-panduan yang akan diaplikasikannya dalam membuat media tiruan. Kata yang diguanakan baku dan kata-kata serta gambar yang ditunjukkan jelas, sehingga sangat menarik perhatian peserta didik, hal ini sesuai dengan pendapat (Tim guru sekolah GM, 2013).

\section{b. Kemenarikan Panduan}

Berdasarkan data rekapitulasi kemenarikan peserta didik, diketahui bahwa pembelajaran yang diterapkan dikelas memperoleh respon yang sangat baik oleh peserta didik secara keseluruhan. Hal ini dibuktikan dengan prosentase kemenarikan positif peserta didik yang menjawab "Ya" sebanyak 97\%, yang artinya tingkat kemenarikan panduan pembuatan media sangat tinggi/sangat menarik. Sedangkan prosentase respon negatif peserta didik yang menjawab "Tidak" sebesar 3\%. Menurut Santrock (1998) secara umum media dapat memberikan umpan balik yang segera kepada peserta didik sehingga peserta didik merasa pembelajaran lebih berinteraksi.

Berdasarkan masukan dan saran dari pakar sekaligus bertindak sebagai validator, perangkat pembelajaran. RPP hasil penilaian dari validator rata-rata 3.6 dari semua komponen Rencana Pelaksanaan Pembelajaran, sehingga dapat dikatakan sangat valid. LKP hasil penilaian dari validator rata-rata 3.2 dari semua komponen Lembar Kegiatan Peserta didik (LKP), sehingga dapat dikatakan sangat valid. Hasil penilaian total rerata validitas tes hasil kreativitas adalah 3.5, sehingga dapat dikatakan instrumen tes kreativitas ini valid. Hasil penilaian total rerata validitas tes hasil kognitif adalah 3.6, sehingga dapat dikatakan instrumen THB kognitif ini sangat valid (Ratumanan, 2006).

Perangkat pembelajaran yang disusun dengan baik merupakan salah satu faktor yang menentukan kualitas pembelajaran. Rancangan perangkat pembelajaran yang dilakukan oleh guru dan juga peneliti hal ini sesuai dengan teori Scaffolding yang diungkapkan oleh Vygotsky (dalam Nur, 2004) yang dapat memberikan bantuan pada peserta didik untuk meningkatkan kemampuan potensialnya.

\section{c. Keterbacaan Panduan}

Tingkat keterbacaan panduan menyatakan tingkat pemahaman peserta didik terhadap panduan yang dikembangkan. Hal ini ditunjukkan oleh data tentang rentang kalimat yang dapat dilengkapi oleh peserta didik dan 92\% menunjukkan bahwa tingkat keterbacaan buku panduan tinggi/mudah dipahami oleh peserta didik, sedangkan yang tidak dimengerti peserta didik pada panduan yaitu $8 \%$.

Keterbacaan ditinjau dari teori pemrosesan informasi dipengaruhi oleh 
banyaknya informasi kedalam memori, salah satunya adalah membangun atensi (perhatian peserta didik) sejak awal pembelajaran dan menyesuaikan materi pembelajaran dengan struktur skemata yang dimiliki oleh peserta didik (Eka, 2009).

\section{Kepraktisan}

\section{a. Keterlaksanaan Pembelajaran}

Keterlaksanaan Rencana Pelaksanaan Pembelajaran (RPP) didasarkan pada pengelolaan KBM, pengelolaan kelas dan pengelolaan waktu. Pengelolaan KBM meliputi pendahuluan, kegiatan inti dan penutup. Hasil Pengamatan Keterlaksanaan Pembelajaran disajikan pada Tabel 1.

Tabel 1. Keterlaksanaan Pembelajaran

\begin{tabular}{|c|c|c|c|c|c|c|c|c|c|}
\hline \multirow{2}{*}{ No } & \multirow{2}{*}{$\begin{array}{l}\text { Kespotan Penheh } \\
\text { juran }\end{array}$} & \multicolumn{2}{|c|}{ HEP I } & \multicolumn{2}{|c|}{ IPP Z } & \multicolumn{2}{|c|}{ EPP 3} & \multirow{2}{*}{$\begin{array}{l}\text { Pats } \\
\text { Bata }\end{array}$} & \multirow{2}{*}{ Kategun } \\
\hline & & $\overline{\mathrm{PI}}$ & $\mathrm{P} 2$ & 31 & 92 & 7 & 82 & & \\
\hline 1 & Perdànánz & 2 & 4 & 3 & 4 & 4 & 4 & 86 & Bisk \\
\hline 2 & 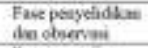 & 4 & 4 & 4 & 4 & 4 & 3 & MS & Sanext bate \\
\hline , & $\begin{array}{l}\text { Pave pengequa } \\
\text { tuhan base }\end{array}$ & 4 & 3 & 4 & 4 & 4 & 4 & 38 & sagyen turik \\
\hline 4 & 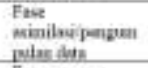 & ? & 4 & 3 & 4 & 4 & 4 & 36 & Boik \\
\hline 5 & $\begin{array}{l}\text { Eve merpor } \\
\text { painailon da }\end{array}$ & 4 & 4 & 3 & 3 & 1 & 4 & 3.5 & anges buk \\
\hline 6 & 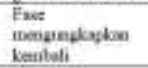 & 3 & 3 & 4 & 4 & 4 & 4 & 36 & Baik \\
\hline 7 & Peraing & 4 & 3 & 4 & 3 & 4 & 4 & 16 & Sragnit balk \\
\hline \multicolumn{2}{|c|}{ Jumiah } & 25 & 25 & 28 & 26 & 27 & $n$ & 25 & . \\
\hline \multicolumn{2}{|c|}{ Rata-roiz Slour } & \multicolumn{2}{|l|}{25} & \multicolumn{2}{|l|}{25.5} & \multicolumn{2}{|l|}{27} & 15 & - \\
\hline \multicolumn{2}{|c|}{ Retliabilita } & \multicolumn{2}{|c|}{$100 \%$} & \multicolumn{2}{|l|}{$98 \%$} & \multicolumn{2}{|c|}{$100 \%$} & 594. & Retiahet \\
\hline
\end{tabular}

Berdasarkan Tabel 1 di atas dapat diketahui bahwa Rata-rata koefesien reliabilitas keterlaksanaan pembelajaran pada ketiga pertemuan adalah 99\%, hasil tersebut melebihi dari $75 \%$. Jadi instrumen tersebut dikategorikan baik (Borich, 1994).

Dengan demikian, instrumen pengamatan keterlaksanaan RPP yang digunakan dalam penelitian ini termasuk kategori baik dan layak digunakan sebagai lembar pengamatan. Hal ini sesuai dengan pendapat Chin (2004), Learning with project based learning can guide students in the construction of knowledge, so that students are more interactive teaching and learning activities. Model PBL dalam kegiatan belajar mengajar akan membangun pengetahun siswa.

Dalam kegiatan inti, peneliti selain menggunakan metode presentasi juga menggunakan demonstrasi media pembelajaran yang dimanipulasi sendiri oleh peserta didik. Berdasarkan hasil keterlaksanaan RPP menunjukkan bahwa apa yang mereka baca di panduan, dan apa yang mereka demonstrasikan akan terekam dalam benaknya. Sesuai dengan teori belajar Teori Pengkodean Ganda yang dikembangkan oleh Paivio (dalam Nur, 2004) yang menghipotesiskan bahwa informasi tersimpan di dalam memori jangka panjang dalam dua bentuk: visual dan verbal, bahwa informasi yang disajikan baik secara visual maupun verbal diingat lebih baik daripada informasi yang hanya disajikan dengan salah satu cara. RPP adalah tugas pokok dari guru dengan mengikuti fase-fase khusus dalam pembelajaran untuk mendampingi peserta didik dalam belajarnya (Winkel W.S,1999).

Selama proses pembelajaran menggunakan panduan pembelajaran dengan menggunakan sintaks model pembelajaran project based learning guru terlebih dahulu dilatih, diberikan penjelasan, melakukan peerteaching, sehingga guru mampu mempresentasikan dan mendemonstrasikan materi dengan menggunakan panduan pembuatan media taktil dan membimbing peserta didik secara baik. Menurut Rizema (2013) bahwa pembelajaran berbasis proyek merupakan suatu pendekatan mengajar yang melatih dan meningkatkan keterampilan berpikir kritis dan kreatif, sekaligus pengetahuan konsepkonsep penting.

\section{b. Kendala-kendala}

Saat kegiatan pembelajaran berlangsung ditemui beberapa kendala. Kendala-kendala yang ditemui adalah sebagai berikut.

Tabel 2. Hambatan-hambatan yang ditemui

\begin{tabular}{|c|c|c|}
\hline Pertemana & Hambatan & Soles Aliteranif \\
\hline 1 & 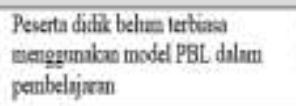 & 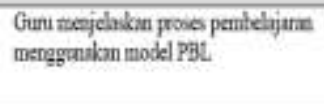 \\
\hline 2 & 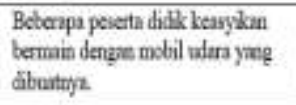 & 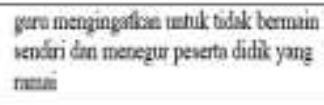 \\
\hline 3 & 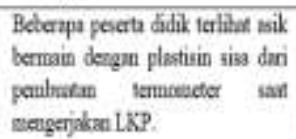 & 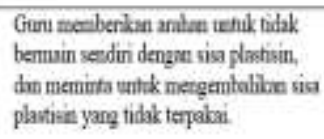 \\
\hline
\end{tabular}


Dari analisa pada tabel 2, dijelaskan bahwa setiap kendala yang ditemui pada saat kegaiatan pembelajaran berlangsung, diberikan solusi yang sesuai dengan masalah yang muncul. Oleh karena itu pembelajaran dengan menggunakan panduan pembuatan media dapat berjalan sesuai dengan rencana.

Arsyad (2007) menyatakan bahwa Peserta didik dalam pembelajaran akan lebih tertarik kepada hal-hal yang nyata, kongkrit, dan dapat dimanipulasi sendiri oleh peserta didik yang berupa media taktil. Hal ini diperkuat oleh pendapat Clausnitzer (1994) bahwa media tiga dimensi dapat memperkuat pemahaman peserta didik.

\section{Keefektifan}

\section{a. Tes Hasil Kreativitas}

Hasil tes kreativitas nilai rata-rata uji awal (pretest) 48,8\%, meningkat menjadi 98,5\% untuk uji akhir (posttest). perubahan skor pada posttest dan pretest dari 25 peserta didik dengan rentang skor 0,9 , yang artinya rentang skor tersebut tinggi. Rata-rata $\mathrm{N}$-(gain) untuk komponen fluency diperoleh skor 3,3; flexibility 2,7; originality 2,8; dan elaboration 2,9. Jadi rata-rata komponen kreativitas tersebut adalah 11,7. Menurut Hake (dalam Djamarah, 2010) jika perubahan skor $>0,7$ maka dapat dikatakan tinggi.

Menurut Setyowati (1995), media mempunyai peranan yang sangat penting dalam menunjang keberhasilan proses belajar mengajar, untuk itu guru perlu menggunakan media secara optimal. Hal ini sesuai dengan teori Piagget dan Vygotsky dalam Rizema, (2013) pedagogi yang baik melibatkan peserta didik untuk melakukan percobaan sendiri, mencoba memanipulasi tanda dan simbol, mencoba bertanya, menemukan sendiri jawabannya, serta membandingkan temuannya dengan temuan anak lain.

Hal ini sesuai dengan pendapat Nyoman (2005) menegaskan bahwa model pembelajaran IPA dalam pembelajaran dapat meningkatkan kreativitas dan kerjasama peserta didik. Selain itu Piriyasurawong (2014) juga menyimpulkan bahwa pembelajaran dengan PBL dapat meningkatkan kreativitas dan pemecahan masalah oleh peserta didik.

Selain itu Dehaan (2016) memberikan pendapat bahwa problem solving with model project based learning can exploration the relationship between creativity and the higherorder cognitive skills for enhancing creativity. Dehaan menjelaskan bahwa model PBL dapat meningkatkan pengetahuan dan kreativitas peserta didik.

\section{b. Tes Hasil Belajar Kognitif}

Tes hasil belajar kognitif diberikan kepada peserta didik sebelum dan sesudah pembelajaran di kelas. Pemberian tes sebelum pembelajaran bertujuan untuk melihat kemampuan awal peserta didik dan pemberian tes setelah pembelajaran bertujuan untuk melihat kemampuan peserta didik setelah diajarkan menggunakan panduan pembuatan media. Peserta didik dikatakan tuntas secara individual minimal $75 \%$ dari seluruh indikator yang diajarkan mengalami ketuntasan (KKM 75). Ketuntasan secara klasikal dikatakan tuntas apabila $75 \%$ dari seluruh peserta didik tuntas secara individual.

Hasil analisis ketuntasan hasil belajar peserta didik dapat dilihat pada Tabel 3.

Tabel 3. Hasil Ketuntasan Hasil Belajar Peserta

\begin{tabular}{|c|c|c|c|c|}
\hline \multirow{2}{*}{$\begin{array}{l}\text { Peserta } \\
\text { didik }\end{array}$} & \multicolumn{2}{|c|}{ Proporsi } & \multicolumn{2}{|c|}{ Ketuntasan } \\
\hline & Pretes & Postes & Pretes & Postes \\
\hline $\mathbf{A B A}$ & 50 & 100 & TT & $\mathrm{T}$ \\
\hline ABB & 50 & 86 & TT & $\mathrm{T}$ \\
\hline ABC & 43 & 93 & TT & $\mathrm{T}$ \\
\hline ABD & 64 & 100 & TT & $\mathrm{T}$ \\
\hline $\mathbf{A B E}$ & 71 & 100 & TT & $\mathrm{T}$ \\
\hline ABF & 57 & 86 & TT & $\mathrm{T}$ \\
\hline ABC: & 57 & 100 & TT & $\mathrm{T}$ \\
\hline ABH & 57 & 93 & TT & $\mathrm{T}$ \\
\hline ABI & 43 & 93 & TT & $\mathrm{T}$ \\
\hline ABJ & 43 & 100 & TT & $\mathrm{T}$ \\
\hline ABK & 64 & 93 & TT & $\mathrm{T}$ \\
\hline ABL & 71 & 93 & TT & $\mathrm{T}$ \\
\hline ABM & 50 & 86 & TT & $\mathrm{T}$ \\
\hline $\mathbf{A B N}$ & 50 & 100 & TT & $T$ \\
\hline ABO & 43 & 93 & TT & $\mathrm{T}$ \\
\hline $\mathbf{A B P}$ & 50 & 86 & TT & $\mathrm{T}$ \\
\hline ABQ & 57 & 100 & TT & $\mathrm{T}$ \\
\hline ABR & 50 & 86 & TT & $\mathrm{T}$ \\
\hline ABS & 43 & 93 & TT & $\mathrm{T}$ \\
\hline ABT & 57 & 93 & TT & $T$ \\
\hline ABU & 71 & 100 & TT & $\mathrm{T}$ \\
\hline ABV & 50 & 100 & TT & $\mathrm{T}$ \\
\hline ABW & 57 & 93 & TT & $\mathrm{T}$ \\
\hline ABX & 43 & 93 & TT & $\mathrm{T}$ \\
\hline ABY & 50 & 100 & TT & $\mathrm{T}$ \\
\hline $\bar{x}$ & 54 & 94 & TT & $\mathbf{T}$ \\
\hline
\end{tabular}


Dari Tabel 3 terlihat bahwa sebelum perlakuan peserta didik dinyatakan tidak tuntas dengan nilai 43-71. Setelah diberikan perlakuan melalui pembelajaran menggunakan media dengan menerapkan model PBL semua peserta didik dinyatakan tuntas. Nilai peserta didik setelah perlakuan adalah 86-100. Selain itu dapat kita lihat grafik tes hasil belajar kognitif berikut ini.

Indikator pada THB kognitif ada 14, yang terdiri dari 14 soal pilihan ganda. Menurut teori Vygosky, Ketuntasan hasil belajar peserta didik tidak terlepas dari peran guru dalam memotivasi kepada peserta didik sehingga tercipta lingkungan belajar yang efektif. THB produk merupakan tes hasil belajar peserta didik dari aktivitas kognitif berdasarkan mengetahui, memahami, berpikir, mempertimbangkan, membandingkan, memilih dan semuanya dengan kesadaran tinggi (Winkel (1999). Hal ini sesuai dengan pendapat Nirmala (2014) menyimpulkan bahwa modalitas visualization, auditory, kinestetic (vak) dapat meningkatkan hasil belajar peserta didik dalam konsep gaya. Lebih jelasnya tes hasil belajar kognitif dapat dilihat pada Gambar1.

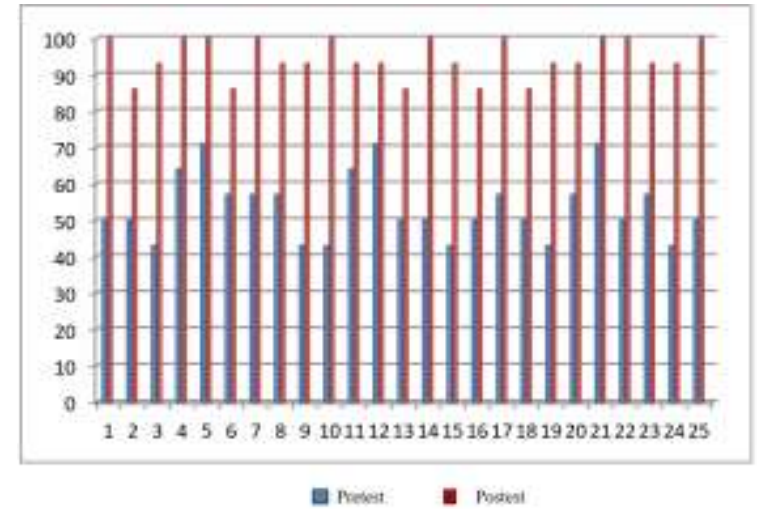

Gambar 1. Tes Hasil Belajar Kognitif Peserta didik

Ketuntasan tujuan pembelajaran pada uji coba I dapat dilihat dalam Tabel 4 dan ketuntasan pembelajaran pada uji coba II dapat dilihat pada Tabel 5
Tabel 4. Ketuntasan Tujuan Pembelajaran Kognitif Peserta didik Uji Coba I

\begin{tabular}{|c|c|c|c|c|c|c|}
\hline \multirow[t]{2}{*}{$\begin{array}{l}\text { No } \\
\text { TPK }\end{array}$} & \multirow[t]{2}{*}{$\begin{array}{l}\text { Ranah } \\
\text { Kognitif }\end{array}$} & \multicolumn{2}{|c|}{$\begin{array}{l}\text { Proporsi } \\
\text { Butir } \\
\text { Soal }\end{array}$} & \multirow{2}{*}{$\begin{array}{l}\text { Sen- } \\
\text { sitivi } \\
\text {-tas }\end{array}$} & \multicolumn{2}{|c|}{$\begin{array}{l}\text { Ketuntasan } \\
\text { TPK }\end{array}$} \\
\hline & & U1 & $\mathbf{U} 2$ & & & \\
\hline 1 & $\mathrm{Cl}$ & 0.6 & 0.9 & 0.3 & 0.9 & $\mathrm{~T}$ \\
\hline 2 & $\mathrm{Cl}$ & 0.5 & 0.8 & 0.3 & 0.8 & $\mathrm{~T}$ \\
\hline 3 & $\mathrm{C}_{2}$ & 0.3 & 0.9 & 0.6 & 0.9 & $\mathrm{~T}$ \\
\hline 4 & C3 & 0.7 & 1 & 0.3 & 1 & $T$ \\
\hline 5 & $\mathrm{Cl}$ & 0.5 & 0.9 & 0.4 & 0.9 & $\mathrm{~T}$ \\
\hline 6 & C3 & 0.7 & 1 & 0.3 & 1 & $\mathrm{~T}$ \\
\hline 7 & $\mathrm{C}_{2}$ & 0.6 & 0.9 & 0.3 & 0.9 & $\mathrm{I}$ \\
\hline 8 & $\mathrm{C}_{4}$ & 0.3 & 1 & 0.7 & 1 & $\mathrm{~T}$ \\
\hline 9 & $\mathrm{Cl}$ & 0.4 & 0.9 & 0.5 & 0.9 & $\mathrm{~T}$ \\
\hline 10 & $\mathrm{C} 2$ & 0.5 & 0.9 & 0.4 & 0.9 & $\mathrm{~T}$ \\
\hline 11 & $\mathrm{C} 3$ & 0.5 & 0.9 & 0.4 & 0.9 & $\mathrm{~T}$ \\
\hline 12 & $\mathrm{C}_{2}$ & 0.6 & 0.9 & 0.3 & 0.9 & $\mathrm{~T}$ \\
\hline 13 & $\mathrm{C} 2$ & 0.6 & 0.9 & 0.3 & 0.9 & $\mathrm{~T}$ \\
\hline 14 & C3 & 0.4 & 1 & 0.6 & 1 & $\mathrm{~T}$ \\
\hline
\end{tabular}

Dari tabel 4 di atas terlihat bahwa pembelajaran menggunakan panduan pembuatan media dapat meningkatkan proporsi jawaban benar peserta didik. Semua TPK tuntas dengan nilai $\geq 0,30$. Untuk soal yang lain memiliki sensitivitas yang tinggi yaitu lebih dari 0,30, dimana butir soal dikatakan memiliki nilai sensitivitas baik menurut Kardi (2001) butir soal tersebut mempunyai tingkat sensitivitas lebih dari 0,30 .

Tabel 5. Ketuntasan Tujuan Pembelajaran Kognitif Peserta didik Uji Coba II

\begin{tabular}{|c|c|c|c|c|c|c|}
\hline \multirow[t]{2}{*}{$\begin{array}{l}\text { No } \\
\text { TPK }\end{array}$} & \multirow[t]{2}{*}{$\begin{array}{l}\text { Ranah } \\
\text { KognitifI }\end{array}$} & $\begin{array}{l}\text { Pro } \\
\text { But } \\
\text { Soa }\end{array}$ & orsi & \multirow[t]{2}{*}{ Sensitivitas } & \multirow{2}{*}{\multicolumn{2}{|c|}{$\begin{array}{l}\text { Ketuntasan } \\
\text { TPK }\end{array}$}} \\
\hline & & $\mathbf{U}_{1}$ & U2 & & & \\
\hline 1 & $\mathrm{Cl}$ & 0.6 & 1 & 0.4 & 1 & $\mathrm{~T}$ \\
\hline 2 & $\mathrm{Cl}$ & 0.6 & 0.9 & 0.3 & 0.9 & $\mathbf{T}$ \\
\hline 3 & $\mathrm{C} 2$ & 0.3 & 0.9 & 0.6 & 0.9 & $\mathrm{~T}$ \\
\hline 4 & C3 & 0.7 & 1 & 0.3 & 1 & $\mathrm{~T}$ \\
\hline 5 & $\mathrm{Cl}$ & 0.5 & 0.9 & 0.4 & 0.9 & $\mathrm{~T}$ \\
\hline 6 & C 3 & 0.7 & 1 & 0.3 & 1 & $\mathrm{~T}$ \\
\hline 7 & $\mathrm{C}_{2}$ & 0.7 & 1 & 0.3 & 1 & $\mathrm{~T}$ \\
\hline 8 & $\mathrm{C} 4$ & 0.3 & 1 & 0.7 & 1 & $\mathbf{T}$ \\
\hline 9 & $\mathrm{Cl}$ & 0.4 & 0.9 & 0.5 & 0.9 & $\mathrm{~T}$ \\
\hline 10 & $\mathrm{C}_{2}$ & 0.5 & 1 & 0.5 & 1 & $\mathrm{~T}$ \\
\hline 11 & $\mathrm{C} 3$ & 0.5 & 1 & 0.5 & 1 & $\mathrm{~T}$ \\
\hline 12 & $\mathrm{C}_{2}$ & 0.7 & 1 & 0.3 & 1 & $\mathrm{~T}$ \\
\hline 13 & $\mathrm{C} 2$ & 0.7 & 1 & 0.3 & 1 & $\mathrm{~T}$ \\
\hline 14 & $\mathrm{C} 3$ & 0.3 & 0.9 & 0.6 & 0.9 & $\mathrm{~T}$ \\
\hline
\end{tabular}

Berdasarkan tabel 5 di atas terlihat bahwa pembelajaran menggunakan panduan pembuatan media dapat meningkatkan proporsi jawaban benar peserta didik. Semua soal tuntas 
TPK. Untuk analisis sensitivitas semua soal sensitif karena memiliki nilai sensitivitas lebih dari 0,30, dimana butir soal dikatakan memiliki nilai sensitivitas baik menurut Kardi (2001) butir soal tersebut mempunyai tingkat sensitivitas lebih dari 0,30.

THB produk merupakan tes hasil belajar peserta didik dari aktivitas kognitif berdasarkan mengetahui, memahami, berpikir, mempertimbangkan, membandingkan, memilih dan semuanya dengan kesadaran tinggi (Winkel (1999). Hal ini juga diperkuat oleh pendapat Gilmore (1974) menyatakan bahwa peserta didik yang aktif adalah orang yang berkontribusi yang positif dari diri seseorang terhadap lingkungannya dimana dia berada. Dengan adanya tindakan yang konstruktif, imaginatif, kreatif, maka diharapkan hasilnya juga akan meningkat. Hal tersebut berkaitan dengan individu yang kreatif, yakni memiliki kepandaian untuk menggunakan pikiran dan perasaannya dalam memecahkan persoalan untuk meningkatkan prestasi yang diraihnya.

\section{Simpulan}

Sesuai dengan hasil temuan yang telah dijabarkan diatas, maka dapat ditarik suatu simpulan yaitu pembelajaran menggunakan panduan pembuatan media taktil yang dikembangkan pada materi energi dan kegunaannya dapat meningkatkan kreativitas dalam kegiatan pembelajaran serta dapat menuntaskan hasil belajar kognitif siswa. Adapun saran dari hasil yang didapatkan adalah sebagai berikut:

1. Persiapan dan pengelolaan waktu perlu diperhatikan, karena pembelajaran menggunakan panduan membutuhkan waktu yang relatif lama.

2. Perlu adanya koordinasi dan diskusi yang baik antara peneliti dan pengamat dengan tujuan untuk mencari masukan dan saran sehingga diperoleh kesamaan persepsi dalam rangka perbaikan untuk pelaksanaan pembelajaran selanjutnya.

3. Perlu dilakukan usaha-usaha yang dapat mengaktifkan peserta didik mempelajari panduan sebelum mengikuti kegiatan pembelajaran di kelas.

4. Jika komponen-komponen model pembelajaran berbasis proyek merupakan hal baru bagi peserta didik, maka sebaiknya memberikan tambahan waktu belajar diluar jam pelajaran sekolah untuk melatihkannya.

\section{Referensi}

Arsyad, Azhar. (2007). Media Pembelajaran. Jakarta: Raja Grafindo Perkasa.

Beetlestone,Florence. (2012). Creative Learning (Strategi Pembelajaran untuk Melesatkan Kreativitas Siswa). Philadelphia:Open University Press $\rightarrow$ diterjemahkan oleh Narulita Yusron.2012. Bandung: Nusa Media.

Borich, G.D. (1994). Observation Skill for Efefective Teaching, $2^{\text {th }}$ Edition. New York: Mac Milan Publishing Company.

Chin, Christine and Li-Gek Chia (2004), Problem-Based Learning: Using Students' Questions To Drive Knowledge Construction. Journal. Volume 88, Issue 5. Wiley Periodicals, Inc.

Clausnitzer and J. W. Hopmans. (1994). Simultaneus Modeling of Transiet Three Dimensional Root Growth and Soil Water Flow. Journal International Volume 164, Issue 2. University of California, USA: Kluwer academic publisher

Dehaan, Robert. (2016). Teaching Creativity and Inventive Problem Solving in Science. Journal International. American Society for Cell Biology. Canada 
Djamarah, Saiful Bahri dan Aswan Zain. (2010). Strategi Belajar Mengajar. Jakarta: Rineka Cipta.

Eka, Fitria. (2009). Pengembangan Media Pembelajaran Biologi SMP Berbasis Komputer Bahan Kajian Sistem Saraf dan Sistem Indera Pada Manusia. Surabaya: UnesaPress

Gilmore, Jhon V. (1974). The Productive Personality. San Francisco: Albion Publishing

Ibrahim, M. (2008). Pengembangan Perangkat Pembelajaran. Modul : Bio-C-06 Direktorat Sekolah Lanjutan Tingkat Pertama Direktorat Jenderal Pendidikan Dasar dan Menengah Departemen Pendidikan Nasional.

Kardi,S. dan Nur M. (2001). Pengajaran Langsung. Surabaya: PSMS. Unesa.

Nirmala, Panca. (2014). Pengaruh Modalitas Visualization, Auditory, Kinestetic (Vak) dalam Meningkatkan Hasil Belajar Siswa dalam Konsep Gaya. Jurnal kalimaya

Nur, Mohamad, Prima Retno Wikandari dan Bambang Sugiarto. (2004). Teori-Teori Pembelajaran Kognitif. Surabaya: PSMS UNESA.

Nyoma, Ngurah Ayu. (2005). Pengembangan Model Pembelajaran IPA di SD Berbasis Masalah untuk Meningkatakan Kreativitas dan Kerjasama Siswa. Semarang: Unnes

Ratumanan, T.G. dan Lourens,T. (2006). Evaluasi Hasil Belajar yang Relevan dengan Kurikulum Berbasis Kompetensi. Surabaya: YP3IT kerjasama dengan Unipress

\footnotetext{
Rizema, Sitiatava. (2013) .Desain Belajar Mengajar Kreatif Berbasis Sains.Yogyakarta: DivaPress
}

Santrock, J. W. (1998). Adolescense.New York. McGraw. Hill Companies,Inc.

Setyowati,N.Nursalim,M.,Azizah,U.,Johan,A., Adriana,A.,Indana,S.(1995).Optimalisa si Penggunaan Alat Peraga IPA dan IPS di Sekolah Dasar Surabaya. Jurnal Riset No.05/Th.III/1996.

Siswono, Tatag Yuli. (2005). Upaya Meningkatkan Kemampuan Berpikir Kreatif Siswa melalui Pengajuan Masalah. Jurnal Pendidikan Matematika dan Sains. FMIPA Universitas Negeri Yogyakarta.

Piriyasurawong. (2014). Project-Based Learning Using Discussion and LessonLearned Methods via Social Media Model for Enhancing Problem Solving Skills.Journal International: Canadian Center of Science and Education.

Tim Guru Sekolah GM. (2013). Buku Panduan Guru SD Mengajar dan Belajar Kreatif. Jakarta: PT. Neo Mediatama.

Widoyoko,Eko Punto. (2014). Hasil Pembelajaran di Sekolah. Jakarta: Pustaka Belajar

Winkel W.S. (1999). Psikologi Pengajaran. Grasindo. Yogyakarta. 